\title{
Customer care services and strategies in academic libraries in KwaZulu-Natal
}

\author{
Petros N. Dlamini ${ }^{\prime}$ \\ Department of Library and Information Science, University of Zululand, South Africa \\ masicane2000@yahoo.com
}

Received: $24^{\text {th }}$ September 2005

Accepted: $10^{\text {th }}$ May 2006

The aim of the study was to investigate customer care services and strategies in academic libraries in tertiary institutions in KwaZulu-Natal. The study used both quantitative and qualitative approaches to collect data from academic staff, students and library staff. The population targeted was sampled using a stratified random sampling technique. Three hundred and eighty six (386) questionnaires were distributed to academic staff and students (library users/customers), and interviews were conducted with fifteen (15) library management, unit and/or committee responsible for customer care. SPSS (Statistical Package for Social Sciences) was used to analyze quantitative data collected from the library users/ customers, and Microsoft Excel was used to analyze data collected from the library staff of the five academic libraries studied. The libraries revealed by the users to have customer care policies in place were Mangosuthu Technikon and the Durban Institute of Technology. In contrast the University of Durban Westville has no customer care policies while at the University of Zululand, there is no difference between those aware and unaware. Interviews with the library staff of the five academic libraries revealed that only two (Mangosuthu Technikon and the University of Natal) have a unit/person responsible for customer care. Furthermore, the results revealed that academic libraries do not have proper methods and strategies for conducting customer care. The findings revealed that library users/customers are generally satisfied with knowledge resources offered to them by their libraries. Subsequently, the study recommends that academic libraries incorporate a unit/person or committee responsible for customer care. Library staff should also be given regular training regarding customer care.

\section{Introduction}

Customers form the structural foundation upon which both public and private sector enterprises are built. The old adage, "the customer is always right" is a necessary tool for the prosperity of any enterprise. Concerns surrounding this issue were expressed by the government in "What is Batho Pele", a policy document or White Paper for Transforming Public Service Delivery (Batho Pele, 1999). Broadly speaking, the focus of the White Paper is encapsulated in eight principles/ guidelines that include consultation, service standards, access, courtesy, information, openness and transparency, redress, best value, innovation and reward, and customer impact. This study was informed by both the above guidelines, and related customer care studies and concepts

Broadly speaking, academic libraries exist to serve mandated students, academic staff, researchers and the community. Hence, they are expected to ensure that all knowledge products and services available are well known and used effectively. However, experience has shown that some service providers, for instance librarians reluctant to improve customer services and strategies, end up having no customers. This study was governed by the notion that if academic libraries take into consideration the importance of customers, there would be tremendous improvement in the use of knowledge resources. The aim of the study was to investigate customer care services and strategies in academic libraries in KwaZulu-Natal. This involved: finding out the composition of customers served by academic libraries in tertiary institutions; establishing whether there are customer care policy structures within the libraries under study; identifying customer care knowledge products and services; verifying whether customer care surveys are conducted in academic libraries; establishing whether library customers are satisfied with library services; and comparing customer care services and strategies in academic libraries in KwaZulu-Natal in order to suggest better practices.

\section{Literature review}

According to Simmonds, Andaleed and Sead (200I) academic libraries are described as the "heart" of academic institutions, providing a base venue from which students and faculty members can conduct research and advance knowledge. The authors deduce that customers of academic libraries can be grouped as either primary customers, consisting mainly of students and staff, or secondary customers, such as alumni, the community and stakeholders.

I. Petros N. Dlamini is a PhD Student at the University of Zululand as well as a Temporary Lecturer at the Durban Institute of Technology, South Africa 
The Empowerment International Customer Care Policy (200I) regards customer care as a tool for solving problems and delivering quality services and products to users. St Martin's College (2004) argue that customer care policies aim to deal with complaints regarding services provided by the public and private sector enterprises in a prompt, fair and positive manner. The authors wish to specify that customer care policies and rules and regulations are complementary. This means that without policy, there would be no rules and regulations. As pointed out by Schuman, (2004) a policy is a general statement supporting library operations, rules, regulations and use. In other words, customer care policies are not specific but general, while rules and regulations are specific. The table below depicts how a customer care policy is related to rules and regulations (St Martin's College, 2004).

Table I Customer Care Policy and Rules and Regulations of Libraries

\begin{tabular}{l|l}
\hline Customer Care Policy is based upon: & Rules and Regulations are based upon: \\
\hline Treating all users with courtesy and respect. & $\begin{array}{l}\text { Membership: all students and academic staff and support staff must have } \\
\text { Library card and borrowing policies. }\end{array}$ \\
$\begin{array}{ll}\text { membership cards in order access the library. } \\
\text { issued without a membership card; and lost, stolen and damaged items are } \\
\text { charged to the borrowers concerned. }\end{array}$ \\
$\begin{array}{l}\text { Terms of borrowing: no item is issued without a membership card; borrowers } \\
\text { are responsible for the safety and security of all items borrowed; and items may be } \\
\text { renewed if not required by another borrower. }\end{array}$ \\
\hline
\end{tabular}
The use of trained and skilled staff to advise, promote and
organize learning resources - accessible to all - both off and on
campus users;
Use of premises and equipment: library users are urged not to make noise in the library; animals such as dogs are not allowed to be brought into the library; smoking is not allowed in the library; eating and drinking are not allowed in the library except for bottled water; and the unauthorized removal of items from the library is forbidden.

Physical and virtual learning environments tailored to the needs of users;

Putting customers/users at the centre of the service and responsiveness to users' needs;

High quality information products and services;

Aim to provide a helpful, friendly and effective service within the constraints of available resources;

Lost material policy

Providing users with the means to submit comments and suggestions and undertake regular surveys of their opinions;

Provide training to a sample of users ensuring that the service rendered is of a high quality;

Being aware of and assisting users with special needs, providing a service free of discrimination

Publicize services and opening hours and keeping users informed of changes; and

The right to ask customers

users to leave the library if they are causing any disturbance to other users.
Vandalizing: it is essential that good care of library materials, properties and equipment is observed.

Use of Resources: use of resources is limited to the user's membership period.

User Satisfaction: the library ensures that it meets and exceeds customer expectations.

Charges: fines are charged for the late return of all library items.

Consultation: the library users are at liberty to consult with library' staff whenever they need assistance. Additionally, the suggestion box is always available for comments from library users.

Educating: the library provides the highest quality products, training and services at all times.

Disability: the library ensures that it is aware of and assists users with disability.

Opening Hours: the library operates during the time stipulated.

Refrain from eating, drinking, smoking and using personal stereos in the library.

With regard to customer service, Mason (2003:15) defines it as a means of having the knowledge and ability to explain important points to both potential and existing customers. According to Banwet and Datta (2003:539) the quality of library services can be divided into two dimensions: the technical (outcome) dimension and the functional (process) dimension. Technical quality, or tangible quality, is expressed primarily through the quality and volume of literature available in the library. Functional quality, or intangible quality, refers to the manner in which library services are rendered. Services achieve quality in perception when levels of performance meet or exceed the level of consumer expectations (Banwet and Datta, 2003:539). According to Leonicio (200I: 53), the underlying philosophy of quality service consists of identifying the customer's power in an age in which ideas are the medium of exchange. This means that within a library organization, the quality of customer service should be a culture of shared values. Banwet and Datta (2003:540), Hernon (2003: I8) and Peter (200I) point out that service quality focuses mainly on the interaction between the customer and the service provider (such as a library), involving an evaluation of specific attributes. Leonicio (2001:53) affirms that customer service has seven characteristics which include: a written statement of customer service 
philosophies; training of employees in effective service delivery; evaluation and measurement of service quality; the use of data to monitor policies, services and operations; an established process of gathering data; service policies that provide latitude for staff to service customers; and an internal customer service program.

According to Cooper and Dempsey (1998:33) customer satisfaction represents the degree to which a library has met the user's needs and expectations. Cooper and Dempsey point out that satisfaction is based on the concept of disconfirmation, which represents the gap that exists between customer expectations and service performance. The authors are of the view that customer satisfaction creates a win-win situation in which libraries gain valuable support from their constituents. The library staff, for instance, attempt to move beyond satisfaction by exceeding user expectations and by addressing the desires of customers through innovation and activity. According to Rowley (1994:9), in the competitive world of information and document delivery channels, libraries need to focus sharply on customer satisfaction, as satisfied customers are returning customers. Rowley describes "quality service" as a service which fulfils customer expectations. This alludes to the fact that good quality library services offer users an experience with which they are satisfied. The author further points out that if customers have narrowly-defined service expectations, they may rate the service offered them as one of good quality despite the fact that other competitive channels may be more satisfying. According to the Marriott Library User Satisfaction Survey (1999), users/customers feel satisfied when library staffs demonstrate genuine focus and interest in their needs and wants. Thus users feel supported through print and online user guides, and instruction sessions and assistance at reference desks, which ensure that they understand searching protocols. The Marriott Library User Satisfaction Survey affirms that users feel satisfied when there is better communication with library staff regarding available help, including printed handouts and online messages and assistance.

With regard to customer care strategies, Stockton (2000) is of the view that institutions are looking to implement a spatially enabled customer care strategy as a means to gain a competitive edge in the market. Thus, this format enhances communication before the sale, offers service positioning and delivery, provides service verification, enables the monitoring of customer satisfaction, marketing, and customer data tacking, and provides analysis' for decision support. Taking good care of customers is the key to success in comparative deregulated institutions. Pawling (200I) suggests that customer care strategies help an organization realize the importance of customers by solving problems faced by users, and increasing satisfaction and empowerment through self service and access to real-time information.

\section{Methodology}

The study was conducted in two phases using a survey design following a pilot study conducted in May 2003. The pilot study garnered experience used to refine the questionnaire, conceptual framework and methodology in the main fieldwork. The main study occurred between June and August 2003. The study covered a representative sample of 386 library users/customers, and 15 library staff. The target population of the study consisted of students, academic staff and library staff from five libraries. The stratified random sampling technique was used to enable the researcher to divide the population into sub-strata. As such, students and academic staff were differentiated according to their levels of study, and constituent faculties. Within selected libraries, random sampling was applied to obtain the actual sample of cases. This method was used to elicit the responses of three hundred and eighty six (386) library users in the University of Zululand, University of Durban Westville (now part of the University of KwaZulu-Natal), Mangosuthu Technikon and the Durban Institute of Technology. Interviews with library staff were consequently undertaken in the University of Zululand (3 library staff members), University of Natal (3 library staff members), Durban Westville University (3 library staff members), Mangosuthu Technikon (3 library staff members) and the Durban Institute of Technology (3 library staff members) in KwaZulu-Natal. The selection of libraries was purposively done as they were the only academic libraries in the Province of KwaZulu-Natal.

A multistage sampling approach involving three stages was used for the investigation. The first stage entailed conducting a census in the tertiary institutions under study, constituting forty one thousand, four hundred and five (4I 405) students and 1536 academic staff. Besides stratified random sampling, judgmental sampling was used to select all professional librarians in the five academic libraries under study. The researcher believes that the students and the academic staff population is homogenous because their characteristics and their use of the library are similar. Following this, views of a small sample of the two groups was likely to be fairly representative. Subsequently, the researcher drew one percent (1\%) from the target population with the aid of the following formula $n / x^{*} \mid 00$ (Leedy 1994: 205). This provided the researcher with a total number of four hundred and thirteen students $(4 I 3)$ and two hundred and forty four (244) academics. In the library staff category, three professional librarians per library were selected.

Data on library customer care was collected using questionnaires and interviews administered to library users/ customers and library staff. These instruments were expected to provide precise and adequate data meeting the requirements of the objectives of the study. Items in the questionnaire had a possible response continuum, measured

SA Jnl Libs \& Info Sci 2006, 72(2) 
using the Likert-scale. The respondents in all four tertiary institutions amounted to a total of four hundred and four (404). In order to ascertain the reliability of the research instruments, a pilot study was conducted to gauge the internal consistency of the items. The pilot study helped to determine the reliability of the instruments by estimating how well items reflecting the same construct yielded similar results. Additionally, the pilot study was conducted with 20 library users: five constituting academic staff while 15 were students. Two of the academic staff were senior librarians at the University of Zululand. The questionnaire was then refined in light of the pre-study experience. Descriptive statistical methods were used for data analysis. These were facilitated using the Statistical Package for Social Sciences (SPSS) and Microsoft Excel. The outcome of the analysis is reflected in the results section below.

\section{Empirical results}

The results responded to the following research questions: a) Which persons constitute library users/customers? b) Does the library in question have a customer care policy? c) Is there any unit and/or person responsible for customer care? d) Are library users/customers satisfied with available knowledge products and services? e) Does the library conduct customer care research? f) What are the strategies of customer care used in the library? These questions formed the main focus of the paper.

\subsection{The academic library customers}

Experience has showed that not all members of the academic community within an academic institution use the library. This notion was verified by asking the respondents to ascertain whether they use the library or not. It was also felt that this study would make more sense if the academic community being investigated as library customers do use the facility.

Table 2 Users/Customers of the academic library $(\mathrm{N}=386)$

\begin{tabular}{llll}
\hline \multirow{2}{*}{ Institutional Affiliation } & \multicolumn{3}{l}{ Customer } \\
\cline { 2 - 4 } & Yes & Sometimes & No \\
& $\mathbf{N}-\%$ & $\mathbf{N}-\%$ & $7(2 \%)$ \\
\hline UNIZUL & $40(10 \%)$ & $17(4 \%)$ & $16(4 \%)$ \\
DIT & $149(39 \%)$ & $52(14 \%)$ & $7(2 \%)$ \\
UDW & $50(13 \%)$ & $11(3 \%)$ & 0 \\
MT & $18(5 \%)$ & $19(5 \%)$ & $30(7.7 \%)$ \\
\hline Total & $257(66.5 \%)$ & $99(25.6 \%)$ & \\
\hline
\end{tabular}

The results indicate that $257(66.5 \%)$ respondents consider themselves users/customers of the academic library, 30 (7.7\%) do not consider themselves as users/customers of the library and $99(25.6 \%)$ are sometimes users/customers of the library. These findings suggest that most students and academic staff consider themselves users/customers of the academic library, even though a few feel that they are not library users/customers.

\subsection{Awareness of customer care policies}

Respondents were required to indicate whether or not their library had a customer care policy. This question allowed respondents to indicate the rules and regulations abided by when using the library. Findings are summarized in the bar chart below.

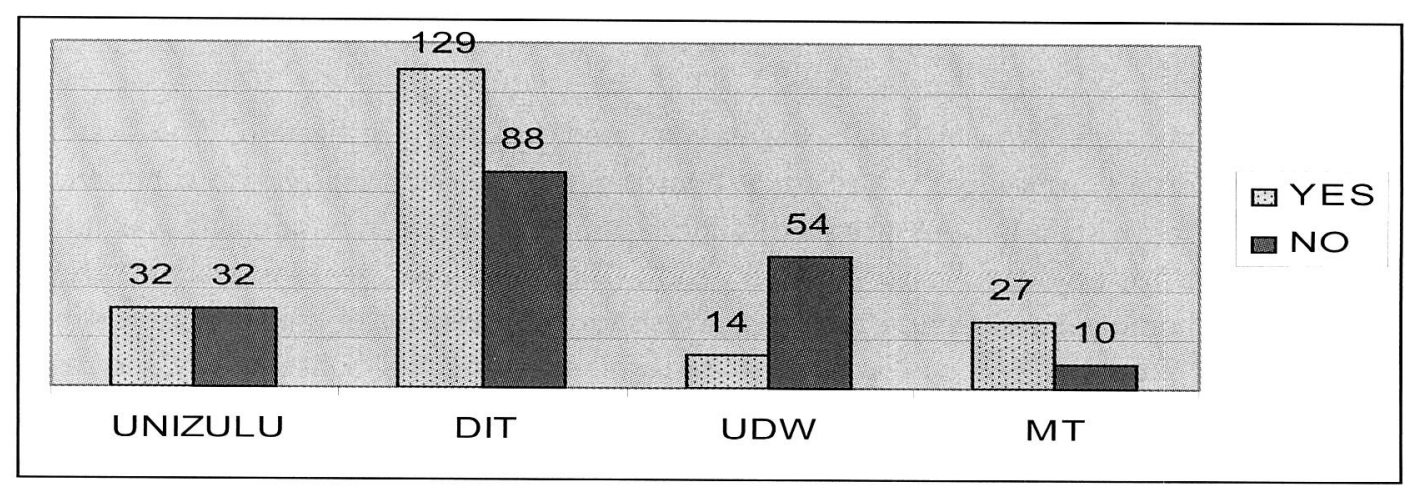

Bar Chart I Awareness of customer care policy $(\mathrm{N}=386)$ 
Above half of the respondents 202 (52\%) were aware of customer care policies, whilst $184(48 \%)$ were unaware of customer care policies within their libraries. At the University of Durban Westville, most $54(79 \%)$ respondents were unaware of a customer care policy. It was observed that in three tertiary institutions, namely the University of Zululand, Durban Institute of Technology and Mangosuthu Technikon, there are customer care policies in place. In contrast, the University of Durban Westville library could not produce any handbook in which rules and regulations are written. This tallies with the response of library users, most of whom are unaware of any rules and regulations.

4.3 Familiarity with customer care policies in the library among the academic staff and students

This item on policy familiarity required respondents to indicate the policy familiar to them when using the library. Table 3 shows the results of respondents regarding policies familiar to them in the library. In the undergraduate category, a high rating of $269(93 \%)$ alluded to using student/staff cards to borrow books. An average rating, that is $125(43 \%)$ respondents, found that their libraries provide quality products, training and services. The results indicate that $11 \%$ of postgraduate students believe that their libraries provide quality service to customers. In the academic category, a high rating, constituting $76(96 \%)$ respondents, use student/staff cards to borrow books from libraries. An average rating of 39 (49\%) was recorded for the policy stating that the library provides the highest quality products, training and services at all times. The overall results indicate that more than $50 \%$ of customer care policies are well known by users, as only a few recorded less than $50 \%$. These results suggest that library customers are familiar with customer care policies within their libraries.

Table 3 Familiarity with library customer care policies $(\mathrm{N}=386)$

\begin{tabular}{|c|c|c|c|c|c|c|}
\hline \multirow{2}{*}{ Policy } & \multicolumn{2}{|c|}{$\begin{array}{l}\text { Undergraduate students } \\
\mathrm{N}=\mathbf{2 8 9} \\
\text { Freq. (N) \% }\end{array}$} & \multicolumn{2}{|c|}{$\begin{array}{l}\text { Postgraduate students } \\
\mathrm{N}=18 \\
\text { Freq. (N) } \%\end{array}$} & \multicolumn{2}{|c|}{$\begin{array}{l}\text { Academic staff } \\
\mathbf{N}=79 \\
\text { Freq. (N) } \%\end{array}$} \\
\hline & 269 & $(93 \%)$ & 18 & $(100 \%)$ & 76 & $(96 \%)$ \\
\hline Return borrowed materials on time & 251 & $(87 \%)$ & 18 & $(100 \%)$ & 75 & $(95 \%)$ \\
\hline $\begin{array}{l}\text { It is essential that good care of library materials, properties } \\
\text { and equipment is observed }\end{array}$ & 202 & $(70 \%)$ & 15 & $(83 \%)$ & 74 & $(94 \%)$ \\
\hline Treat library and fellow users with respect and courtesy & 211 & $(73 \%)$ & 13 & $(72 \%)$ & 59 & $(74 \%)$ \\
\hline $\begin{array}{l}\text { Refrain from eating, drinking, smoking and using personal } \\
\text { stereos in the library }\end{array}$ & 206 & $(7 \mid \%)$ & 10 & $(56 \%)$ & 53 & $(67 \%)$ \\
\hline $\begin{array}{l}\text { Users are at liberty to consult with library staff whenever } \\
\text { they need assistance }\end{array}$ & 201 & $(70 \%)$ & 14 & $(78 \%)$ & 52 & $(66 \%)$ \\
\hline Tearing or mutilating of books is forbidden & 194 & $(67 \%)$ & 8 & $(44 \%)$ & 55 & $(70 \%)$ \\
\hline $\begin{array}{l}\text { The library provides a service, which is friendly and helpful } \\
\text { to customers }\end{array}$ & 178 & $(62 \%)$ & 4 & $(22 \%)$ & 47 & (59\%) \\
\hline $\begin{array}{l}\text { The library creates a pleasant and welcoming environment } \\
\text { in which users can work }\end{array}$ & 160 & $(55 \%)$ & 4 & $(22 \%)$ & 41 & $(52 \%)$ \\
\hline $\begin{array}{l}\text { The library makes available materials and information } \\
\text { resources }\end{array}$ & 151 & $(52 \%)$ & 4 & $(22 \%)$ & 47 & $(59 \%)$ \\
\hline $\begin{array}{l}\text { The library publicizes the library's range of services, library } \\
\text { regulations and opening hours }\end{array}$ & 154 & $(53 \%)$ & 4 & $(22 \%)$ & 47 & (59\%) \\
\hline $\begin{array}{l}\text { The library provides the fullest possible service at all times } \\
\text { to customers and is appropriate to users' needs }\end{array}$ & 157 & $(54 \%)$ & 5 & $(28 \%)$ & 41 & $(52 \%)$ \\
\hline Be aware of and assist users with disability & 133 & $(46 \%)$ & 3 & $(\mid 7 \%)$ & 45 & $(57 \%)$ \\
\hline $\begin{array}{l}\text { The library services meet and exceed customer } \\
\text { expectations }\end{array}$ & 125 & $(43 \%)$ & 2 & $(11 \%)$ & 43 & $(54 \%)$ \\
\hline $\begin{array}{l}\text { The library provides the highest quality products, training } \\
\text { and services at all times }\end{array}$ & 125 & $(43 \%)$ & 2 & (| |\%) & 39 & $(49 \%)$ \\
\hline
\end{tabular}

\subsection{Unit/person responsible for customer care}

Respondents were required to indicate whether or not they were aware of a customer care unit/ person within the library. The purpose of this question was to find out if the library had a unit or person responsible for customer care services within the library, and whether such a unit/person is known to customers. Bar chart 2 below shows the results. 


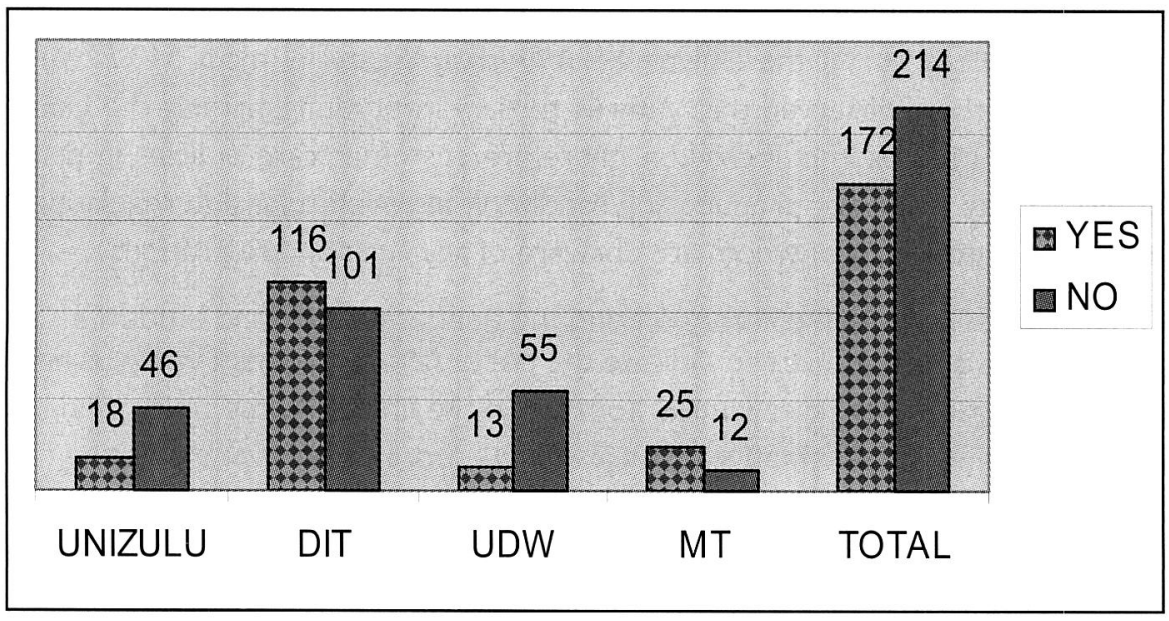

Bar Chart 2 Unit/committee/person responsible for customer care services and strategies.

Above half, that is 214 (55\%), were unaware of any unit/person/committee responsible for customer care services and strategies, while $172(45 \%)$ revealed that they were aware of a customer unit/person/committee in the library. Additionally, the results reveal that library users were aware of the unit/person/committee responsible for customercare services and strategies at Mangosuthu Technikon and the Durban Institute of technology.

4.5 Frequency of visiting the library by users

Respondents were requested to indicate how frequently they use the library. They had to choose between regularly, sometimes weekly or monthly, and never. The results are summarized in Table 4 below.

Table 4 Frequency of using the library by users $(\mathrm{N}=386)$

\begin{tabular}{|c|c|c|c|}
\hline \multirow[t]{2}{*}{ Students and Academic staff } & \multicolumn{3}{|l|}{ Frequency of using the library } \\
\hline & Regular ( $1-5$ times a week) & Sometimes (weekly or monthly) & Neverr \\
\hline Undergraduate & $112(38 \%)$ & $169(58 \%)$ & $7(2 \%)$ \\
\hline Postgraduate & II (61\%) & $7(39 \%)$ & 0 \\
\hline Academic Staff & $20(25 \%)$ & $56(71 \%)$ & $3(4 \%)$ \\
\hline
\end{tabular}

One hundred and twenty three $123(38 \%)$ undergraduate respondents stated that they visit the libraries regularly, 169 $(58 \%)$ sometimes (weekly or monthly) and $7(2 \%)$ never visit the libraries. In the postgraduate category, II $(61 \%)$ revealed that they visit the libraries regularly and 7 (39\%) sometimes (weekly or monthly). $20(25 \%)$ respondents from the academic staff category were found to visit the libraries regularly, while $56(71 \%)$ indicated sometimes, and $3(4 \%)$ never visit the libraries. The results show that the majority of library users/customers visit the library regularly.

4.6 Awareness of knowledge products and services offered

The empirical results of respondent's awareness of knowledge products and services offered by their libraries are shown in the bar chart below.

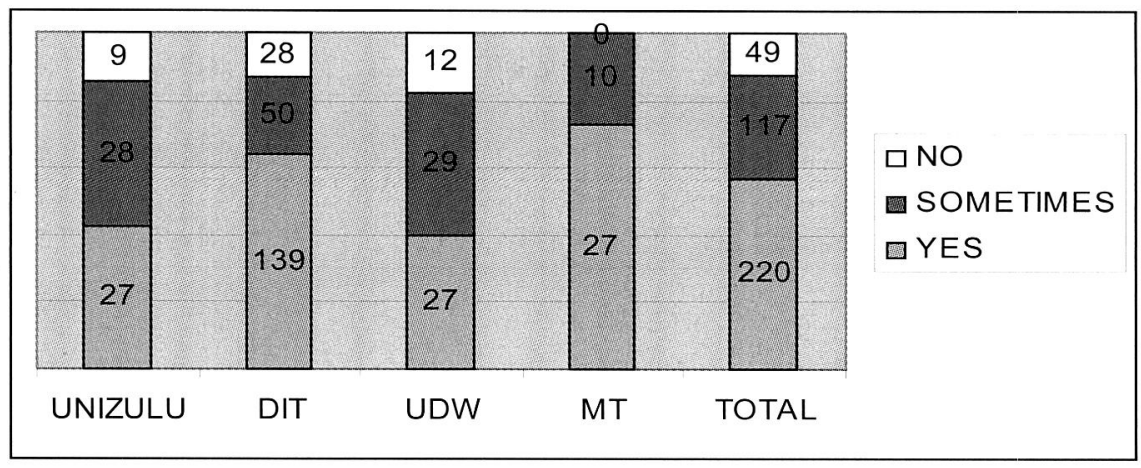

Bar Chart 3 Awareness of knowledge products and services offered $(\mathrm{N}=386)$ 
The findings reveal that most, $220(57 \%)$, respondents were aware of knowledge products and services, while II7 (30\%) indicated sometimes, and 49 (13\%) stated that they were unaware. These findings suggest that most respondents are aware of knowledge products and services offered by their libraries.

4.7 Identification of knowledge products and services in the libraries

Table 5 shows the results of knowledge products and services familiar to library customers. More than $50 \%$ of postgraduate and undergraduate students were able to identify knowledge products and services in the libraries. In contrast, less than $50 \%$ of the academic staff were familiar with knowledge products and services. These findings conclude that the more library user/customers visit the library, the more they become familiar with knowledge products and services offered.

\subsection{Awareness of customer care survey and methods}

Respondents were required to indicate whether they were aware of library customer care surveys. The purpose of this item was to observe if respondents were aware of or have been involved in customer care surveys. The results are summarized in Bar Chart 4.

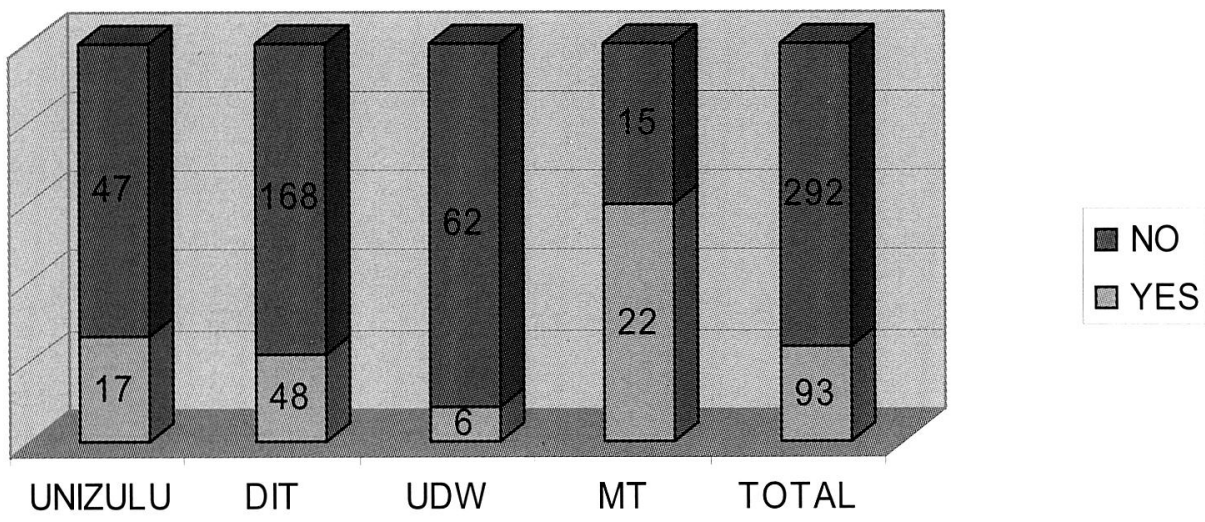

Bar Chart 4 Awareness of customer care survey methods $(\mathrm{N}=386)$

Bar chart 4 above, shows that most, 292 (76\%), respondents were unaware of any customer care surveys in academic libraries. Only $92(24 \%)$ stated that they were aware of customer care survey methods. These findings suggest that customer care survey methods are generally unknown to library users/customers within their respective libraries. However, at Mangosuthu Technikon, the library users/customers were aware of customer care survey methods. This may be alluded to the fact that there is a unit/person responsible for customer care.

Table 5 Identification of knowledge products and services in the library $(\mathrm{N}=386)$

\begin{tabular}{|c|c|c|c|c|c|c|}
\hline \multirow[t]{2}{*}{ Products and Services } & \multicolumn{6}{|c|}{ Customer category } \\
\hline & \multicolumn{2}{|c|}{$\begin{array}{l}\mathrm{N}=\mathbf{2 8 9} \\
\text { Undergraduate } \\
\text { Freq. } \%\end{array}$} & \multicolumn{2}{|c|}{$\begin{array}{l}\mathrm{N}=18 \\
\text { Postgraduate } \\
\text { Freq. } \%\end{array}$} & \multicolumn{2}{|c|}{$\begin{array}{l}\mathrm{N}=79 \\
\text { Academic } \\
\text { Freq. } \%\end{array}$} \\
\hline Books & 283 & $(98 \%)$ & 17 & $(94 \%)$ & 79 & $(100 \%)$ \\
\hline Newspapers & 226 & $(78 \%)$ & 14 & $(78 \%)$ & 56 & $(71 \%)$ \\
\hline Magazines & 191 & $(66 \%)$ & 13 & $(72 \%)$ & 55 & $(70 \%)$ \\
\hline Journals & 214 & $(74 \%)$ & 17 & (94\%) & 73 & $(92 \%)$ \\
\hline Reference sources (e.g. dictionaries and encyclopedias) & 210 & $(73 \%)$ & 16 & (89\%) & 51 & $(65 \%)$ \\
\hline Grey Literature (e.g. minutes of meetings and correspondence) & 83 & (29\%) & 9 & $(50 \%)$ & 31 & $(39 \%)$ \\
\hline Conference proceedings & 61 & $(21 \%)$ & 12 & $(67 \%)$ & 25 & $(32 \%)$ \\
\hline Industrial and commercial literature (e.g. patens and designs) & 51 & $(18 \%)$ & 11 & $(61 \%)$ & 24 & $(30 \%)$ \\
\hline Research reports (e.g. theses and dissertation) & 135 & $(47 \%)$ & 15 & $(83 \%)$ & 40 & $(5 \mid \%)$ \\
\hline Official and government publications (e.g. legislations) & 112 & (39\%) & 12 & $(67 \%)$ & 25 & $(32 \%)$ \\
\hline Past examination papers & 167 & $(58 \%)$ & 15 & $(83 \%)$ & 31 & $(39 \%)$ \\
\hline Internet and e-mail (with the help of the librarian) & 144 & $(50 \%)$ & 10 & $(56 \%)$ & 32 & $(4 \mid \%)$ \\
\hline Short Loan Services & 157 & $(54 \%)$ & 15 & $(83 \%)$ & 43 & $(54 \%)$ \\
\hline
\end{tabular}




\begin{tabular}{|c|c|c|c|c|c|c|}
\hline Interlending Services & 104 & $(36 \%)$ & 13 & $(72 \%)$ & 40 & $(5 \mid \%)$ \\
\hline Lending Services & 144 & $(50 \%)$ & 14 & $(78 \%)$ & 27 & $(34 \%)$ \\
\hline Audiovisual Services (e.g. use of TV and CD-ROMs) & 112 & $(39 \%)$ & 11 & $(6 \mid \%)$ & 38 & $(48 \%)$ \\
\hline Referral and Reference services & 210 & $(73 \%)$ & 18 & $(100 \%)$ & 20 & $(25 \%)$ \\
\hline Photocopying & 166 & $(57 \%)$ & 13 & $(72 \%)$ & 33 & $(42 \%)$ \\
\hline Orientation & 129 & $(45 \%)$ & 15 & $(83 \%)$ & 20 & $(25 \%)$ \\
\hline Customer consultation and advisory (by the librarian) services & 179 & $(62 \%)$ & 18 & $(100 \%)$ & 17 & $(21 \%)$ \\
\hline Reading (use of library reading rooms) & 117 & $(40 \%)$ & 12 & $(67 \%)$ & 24 & $(30 \%)$ \\
\hline Information Literacy Services & 98 & $(34 \%)$ & 17 & $(94 \%)$ & 12 & $(15 \%)$ \\
\hline Use of Special Collection (e.g. Africana/Uzulu collection) & 179 & $(62 \%)$ & 15 & $(83 \%)$ & 23 & $(29 \%)$ \\
\hline Displays and exhibitions & 15 & $(.05 \%)$ & 0 & $(0 \%)$ & 21 & $(27 \%)$ \\
\hline
\end{tabular}

4.9 Customer satisfaction on knowledge products and services

Bar Chart 5 summarizes the findings on customer satisfaction with regard to library products and services.

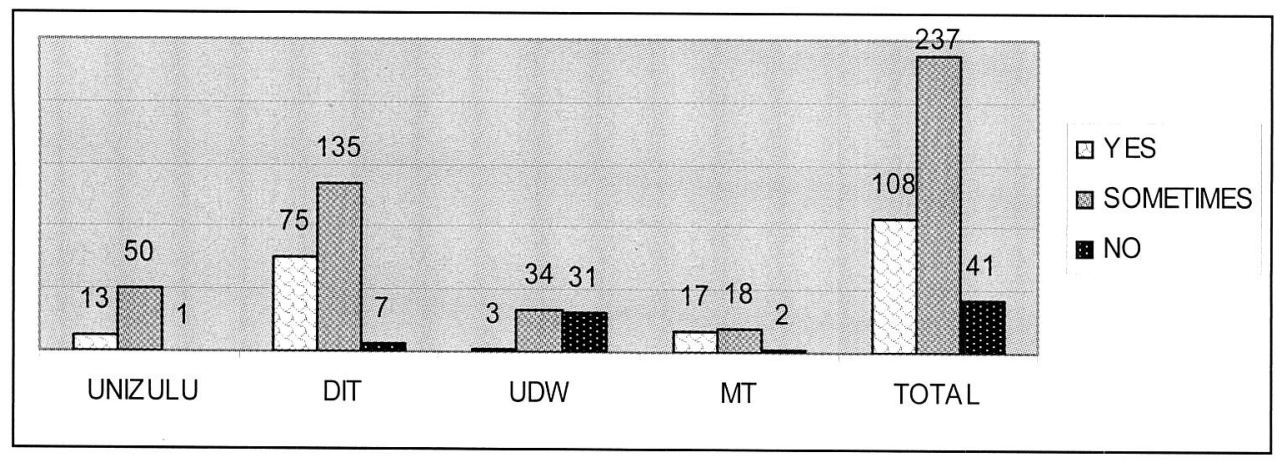

Bar Chart 5 Customer satisfaction $(\mathrm{N}=386)$

The above results indicate that $108(28 \%)$ respondents were satisfied, while most, $237(61 \%)$, respondents were sometimes satisfied with knowledge products and services offered, and 4 I (II\%) were not satisfied at all. Even though the results reflect that library users/customers are generally satisfied with knowledge products and services, findings at the University of Durban Westville indicate that there is no difference between those who are and those who are not satisfied.

4.10 Awareness of strategies of customer care

The bar chart below summarizes results regarding the awareness of strategies of customer care in libraries.

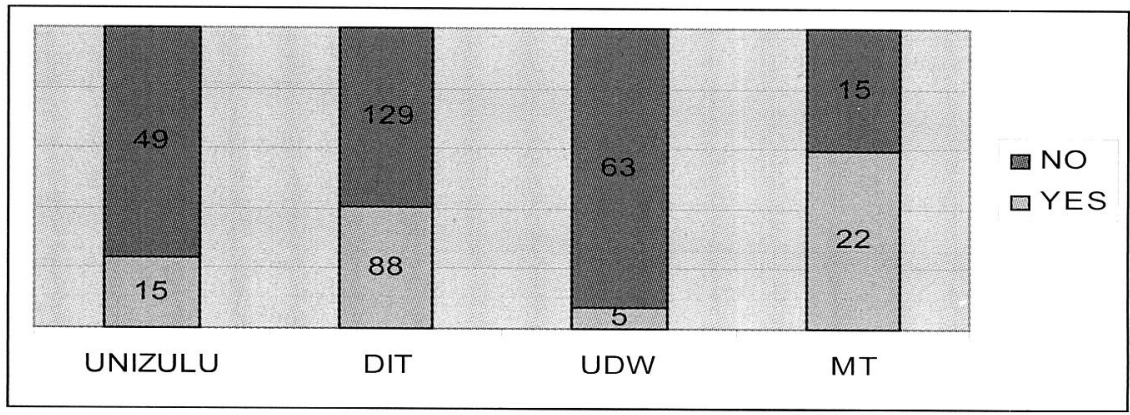

Bar Chart 6 Awareness of customer care strategies $(\mathrm{N}=386)$

The empirical results indicate that I5 (23\%) respondents from the University of Zululand were aware of customer care strategies, while $49(77 \%)$ were not aware of any customer care strategies within their library. Eighteen 18 (4l\%) respondents from the Durban Institute of Technology revealed that they were aware of customer care strategies, while $129(59 \%)$ were not aware. Only $5(7 \%)$, respondents from the University of Durban-Westville were aware of customer care strategies within their library, while 63 (93\%) indicated that they were not aware. Twenty two ( 22) 59\% respondents from Mangosuthu Technikon indicated awareness, while $15(41 \%)$ were not aware of any strategies. These 
results indicate that strategies of customer care are unknown by the majority of respondents, even though they are known at Mangosuthu Technikon.

\section{Results from interviews with library staff}

This section provides interview results obtained from management staff in the libraries cited. As mentioned earlier, students and academic staff from the University of Natal were excluded, the researcher was able to interview library staff of the aforementioned institution. The study sample consisted of 15 professional librarians from all the academic libraries. This selection was based on results from the pilot study that revealed internal consistency in the instruments used for data collection. Thus it was felt that the sample size was adequate as a tool for providing accurate information. The results indicate that academic libraries serve the same customers as those identified earlier, meaning students, academic and administrative staff, researchers and external students from other institutions, other University staff or Technikon staff as well as library colleagues and the business community.

\subsection{Customer care policies}

Nine $(60 \%)$ respondents from the University of Zululand, the Durban Institute of Technology and the University of Durban Westville indicated that there were no customer care policies in place at their libraries. 6 (40\%) respondents from Mangosuthu Technikon and the University of Natal reported that they have customer care policies in place. Nevertheless, the rules and regulations of the five academic libraries were found to be similar, despite the fact that the latter three do not have customer care policies in place

With regard to the unit or person responsible for customer care/services within the library, again the University of Zululand, the Durban Institute of Technology and the University of Durban Westville reported that there is no unit/ person responsible for customer care within their respective libraries, and that all librarians are, in some way, responsible entities. However, at Mangosuthu Technikon and the University of Natal, all 6 (40\%) respondents revealed that there is a unit/committee/person responsible for customer care within their libraries, including the head of the circulation desk, and the special projects librarian, who is in charge of user education, information literacy and customer services.

\subsection{Recognition of knowledge products and services offered by the library}

Libraries generally own similar knowledge products and services, identified by library customers as: books; newspapers; reference sources; magazines; video cassettes; radio cassettes; microfilm; electronic databases; government publications and reports; theses; books on CD ROMs; electronic books; and library newsletters. Responses to knowledge services included: reprographic/photocopier; renewals of user cards; user education; orientation; displays and exhibitions; serial librarian services; subject librarian services; and binding. Mangosuthu Technikon was found to have additional knowledge services in graphic design, media, lending equipment such as video cameras, OHP, and teaching masters.

\subsection{Methods of conducting customer care surveys}

Librarians identified the following methods, arranged in order of popularity:

- Opinion polls (suggestion boxes);

- Customer care surveys;

- User education;

- Interviews and

- Orientation and focus groups.

\subsection{Library staff perceptions of customer satisfaction}

The library staff offered interesting perceptions on how they ensure customer satisfaction using available knowledge products and services. Again, respondents from all the academic libraries had similar perceptions regarding this issue. They reported the following: most staff work through lunch and tea time; staff come to work even during vacation to put everything in place; the staff provides options to library users/customers offering training when necessary; and contact information is available to customers ensuring that they can always be reached whenever the need arises. Furthermore, respondents from the Universities of Zululand and Natal were found to be ahead of other libraries in satisfying library customers through resource sharing, searching and retrieving information for customers, and printing.

Customer care strategies were important to obtain from librarians. It was found that all academic libraries have customer care strategies, which include: sales and marketing (displays and exhibitions); user education and training; library guides; profiles regarding current awareness; and the library news letter. Respondents from Mangosuthu Technikon added that they have competitions (e.g. poetry, speed-reading and design signage). The University of Natal also mentioned that seminars are often conducted, educating academic staff and new staff on library use. 


\section{Discussion}

The study found that academic libraries have and serve similar customers. Most (66\%) students and academic staff felt that they were customers of the academic library. Their responses are in agreement with findings from the library staff that students and academic staff are viewed as customers of the academic library. The views of library customers and library staff are similar with those of Simmonds, Andaleed and Sead (200I), in which they observe that it is "almost a universal acknowledgement that academic libraries are the hearts of the institutions. This is because who ever works, learns or visits the institution depends heavily on the library to get relevant information".

With regard to the awareness of customer care policies among library users/customers, above half (52\%) of the respondents revealed that they were aware of customer care policies within their libraries. To indicate their level of awareness, students and academic staff had to identify customer care policies (rules and regulations) familiar to them within the library (see Table 5). It is necessary to point out that the awareness of the availability of customer care policies varies from institution to institution. At the University of Zululand, the findings from the library users/customers indicated that there is no difference between those who are aware and those who are not aware of the availability of customer care policies. The library staff also indicated that there is no customer care policy in place within this particular library. The researcher observed that the library users/customers from Mangosuthu Technikon and the Durban Institute of Technology were aware of customer care policies. However, with regard to library staff at the Durban Institute of Technology, they all revealed that there is no customer care policy in place, whereas at Mangosuthu Technikon, the library staff revealed that customer care policy does exist within the library. On the other hand, it was noted that of the 68 students and academic staff assessed from the University of Durban-Westville, the majority, 54 (79\%), stated that they were unaware of customer care policies. The results gathered from library users/customers at the University of Durban Westville library concord with those of library staff that customer care policy is not in place in the library. Hence, this study suggests that there is an urgent need for library staff to be trained in customer care, particularly regarding policy issues, especially in academic libraries that rated very low in policy availability

The study found that $214(55 \%)$ students and academic staff were unaware of a unit/person responsible for customer care within their library. Their views concur with the information gathered from the library staff respondents. Some argued or suggested that all of them are both directly and indirectly involved with customers. Of the 37 respondents from Mangosuthu Technikon, most $(25 ; 68 \%)$ revealed that there is a unit/person responsible for customer care. Their responses also are similar with results from the library staff, both reporting that there is a special project librarian and a committee responsible for customer care. The results from the library users/customers in the Universities of Zululand and Durban Westville proved negative. The library users/customers could not identify a unit/person, responsible for customer care in their respective libraries. The researcher notes that even if library users receive search and orientation training, endeavours such as these would be futile without a proper unit/person responsible for customer care to whom queries can be voiced.

The library users/customers had also been asked if they were aware of knowledge products and services. The results revealed that the library users/customers are aware of knowledge products and services offered by their libraries. The study observed that the knowledge products and services scored high ratings, above $50 \%$. Also noted was the fact that the awareness of knowledge products and services among students and academic staff is dependent on the currency of knowledge resources for user needs. Broadly speaking, currency of information brings about stability and greater use of knowledge resources as it makes the library user-friendly. The findings revealed that $27 \mathrm{I}(70 \%)$, respondents access knowledge resources which are 5-10 years old. At the University of Durban Westville library, 47 (69\%) respondents were of the opinion that the knowledge resources were not current or out dated (10-20 years old). This suggests that the library resources at the University of Durban-Westville are somehow outdated. The majority $(237 ; 61 \%)$ of library users/ customers revealed that they were sometimes satisfied with knowledge products and services offered. The responses obtained from the library staff concur with those of students and academic staff. Most library users were found to fully appreciate the services offered to them. This was revealed when the library staff respondents stated that training is offered to students and academic staff whenever necessary (see section 5.4). This information is similar with the Marriot Library User Satisfaction Survey (1999), in which it is affirmed that customers/users feel satisfied when library staff demonstrate genuine focus and interest in customer needs and wants. Furthermore, the library staff respondents from Mangosuthu Technikon mentioned that they organize reading competitions among library users, thus encouraging them to use the library (e.g. a user who finishes reading within a stipulated time obtains first prize).

Pawling (200I) points out that customer care strategies help an organization solve problems faced by users/customers whilst increasing satisfaction, in addition to empowering customers with self service capabilities and access to real-time information. Even though customer care strategies solve problems faced by users in increasing satisfaction, most (256 or $66 \%)$ students and academic staff indicated that they were unaware of customer care strategies within their libraries. 
These findings stipulate that almost all of the students and academic staff could not identify customer care strategies familiar to them in their libraries. Pawling (200!) identifies customer care strategies as: customer care technology, utility call centers, sales and marketing, customer service and tactics. Half of the customer care strategies indicated by the library staff respondents do not concur with those mentioned by the two sources cited above. Evidently, academic libraries either do not have proper customer care strategies in place, or existing structures are unknown among library staff members and users/customers.

\section{Conclusions}

The study points out that academic libraries have and serve similar customers who rely heavily on the use of knowledge products and services offered. 257 (65\%) student and academic staff respondents revealed that they are library users/ customers. Their views concur with Mgobozi (2002:6) that the purpose of academic libraries is to serve students, academic staff, administrative staff, library staff, the neighbouring community and researchers with knowledge products and services. With regard to customer care policies, the study recommends vigorous training for librarians, equipping them with dynamic service delivery skills as indicated by the Batho Pele (White Paper). The aforementioned view would attune academic libraries with the literature of the Royal Borough of Windsor and Maidenhead (2002:7), which states that customer care policies set the standards against which individual users and communities can measure their needs, rights and expectations. Thus it covers all aspects of accessibility to library services including location, opening hours, physical access, furniture and equipment, stock and services, access to staff and adequate space".

The findings of the study indicate that there are sufficient knowledge products and services offered by academic libraries. Thus, the majority 220 (57\%) of library users/customers are generally satisfied with knowledge resources offered. These findings reveal that academic libraries generally fulfill information requirements. This suggests a paradox: that despite inadequacies in customer care policies and the lack of a unit/person/committee responsible for customer care, library users/customers are generally satisfied with knowledge products and services. In essence, the findings reveal that these academic libraries lack proper methods and strategies in dealing with customer care. However, improper methods and strategies do not prevent library users/customers from being aware of available knowledge products and services.

It is viable to point out that the unavailability of these proper methods and strategies bring down the image of academic libraries. Academic libraries are not exempt from the eight principles of Batho Pele, involving: consultation; service standards; access; courtesy; information; openness and transparency; redress; best value; innovation and reward; and customer impact. The researcher would like to propose that customer care strategies and the eight principles of Batho Pele be put in place in academic libraries. I believe that this would enable academic libraries in KwaZulu Natal and South Africa as a whole to win the hearts of customers, since satisfied customers are returning customers.

\section{References}

Banwet, D. K. and Datta, B. (2003). Effect of service quality on post-visit intentions over time: the case of a library. Total quality management. Vol, 13, No 4, p 537-546.

Batho Pele. (1999). Batho Pele (People First). South Africa: [Online]. http://www.kwazulunatal.gov.za/premier/batho_pele/ what_is.htm. [Accessed 20/10/2003].

Brumley, R. and Schuman, N. (2004). Library Policies and General Information. [Available On-line]. http://www.wmrls.org/ policies/6regions/policies.html. [Assessed 21/04/06]

Cooper, R. and Dempsey, P.R. (1998). Remote library user's needs and expectations. Library trends, Vol. 47. Issue I.

Hernon, P. (2003). Editorial: first embracing customer service, second moving beyond it. A client relationship. Journal of Academic Librarianship. Vol.28, Issue 4

Leedy, P.D. (1994). Practical research. Planning and designing. $6^{\text {th }}$ ed. Upper Saddle River: Merrill

Leonicio, M. (200I). Going the extra mile: Customer service with a smile. Haworth Information Press.

Marrott Library User Satisfaction Survey. (1999). [On-line]: http://www.arl.org/libqual/events/Oct2000msq/papers/Simmonds/ simmonds.html: [Accessed on I5/04/03]

Mason, C. (2003). The pandora's box of customer service, American Network, Vol. I04, Issue I p. I0-I5.

Mgobozi, M.N. (2002). The use of electronic journals for the Dissemination of scholarly information by the University of Natal and the University of Zululand. South Africa Journal of Library and Information Science, 8 (2): 8I-93.

Pawling, G.P. (200I). Five steps to better customer care. Use internet strategies to improve customer service and customer satisfaction. New Jersey: [On-line]: http://www.google.com/search?hl=en\&ie=UTF$8 \& q=$ Five + steps + to + better + customer + care +Use + internet + strategies: [Accessed on 04/04/03]

Peter, H. (200I). Service quality. Journal of Academic Librarianship. Vol. 27, Issue 5. [On-line]: http://search.epnet.com/ direct.asp?an=5374252\&db=aph: [Accessed on 15/05/03].

Rowley, J. (1994). Customer experience of libraries. Library review. Vol. 43 No (6) p. 7-I5.

Simmonds, P.L. and Andaleeb, S.S. (200I). Usage of academic libraries: The role of service quality, resources, and user characteristics. Library trends. [On-line]: http://web3.epnet.com/citation.asp?tb=: [Accessed on I5/05/03]. 
St Martin's College. (2004). Customer Care Policy. Library services online. London: [On-Line] http://www.ucsin.ac.uk/library/ policiesandregulations/customercare/index.php. [13/08/2004].

Stockton, E.M. (2000). Geospatial customer care strategies in a competitive utility market.Englewood: [On-line]: http:// www.gisdevelopment.net/proceedings/gita/2000/ibnw/ibnw007pf.htm: [Accessed on 16/04/03].

The Empowerment International Customer Care Policy. (200I). Customer care in libraries. New York.

The Royal Borough of Windsor and Maidenhead. (2002). Leisure, cultural and property services: customer services unit. Policies and Standards. New York: Department of Culture, Media and Sports. 